\title{
Tibet and China: The Interpretation of History
} Since 1950

\section{Elliot Sperling}

\section{Q OpenEdition}

1 Journals

Édition électronique

URL : http://journals.openedition.org/chinaperspectives/4839

DOI : 10.4000/chinaperspectives.4839

ISSN : 1996-4617

Éditeur

Centre d'étude français sur la Chine contemporaine

\section{Édition imprimée}

Date de publication : 1 septembre 2009

ISSN : 2070-3449

Référence électronique

Elliot Sperling, «Tibet and China: The Interpretation of History Since 1950 », China Perspectives [En ligne], 2009/3 | 2009, mis en ligne le 01 septembre 2012, consulté le 28 octobre 2019. URL : http:// journals.openedition.org/chinaperspectives/4839; DOI : 10.4000/chinaperspectives.4839 


\title{
Tibet and China: The Interpretation of History Since 1950
}

\author{
ELLIOT SPERLING
}

This article examines the way Tibet's history and its relations with China have been interpreted and described in China since 1950. While China has long claimed that Tibet became part of China in the thirteenth century under the Yuan Dynasty, much evidence shows that this interpretation is a twentieth century construction. A more assertive Chinese position holds that historical China consists of the territory of the Qing Dynasty at its height, and that all within those boundaries have been uniquely part of China since ancient times, well before the Yuan era, and indeed since before the beginning of recorded history.

"History tells truth

Tibet, part of China"

$\square$ or several months in late 2008, the China Central Television (CCTV) website carried a set of statements under the above banner designed to highlight China's proper sovereignty over Tibet via recourse to history as the arbiter of that sovereignty. As much as anything else, this indicates rather clearly the importance China attaches to history as an element in its polemical campaign over Tibet. Of course, the issue of Tibet itself is composed of diverse components: there are questions of human rights, demographics, development, language usage, etc. But the question of history touches one particular nerve in this complex: the matter of Tibet's status and, therefore, the question of the legitimacy of its incorporation into the People's Republic of China.

There are parties to the Tibet question who would like to see the historical question settled, or at least ignored, as an inconvenient impediment to a discussion of concrete steps to resolve the issue in the present day. But even here the bases for side-stepping the question of Tibet's status are often formulated differently. Those outside China will often contend that the incorporation of Tibet into China is simply an irreversible fait accompli. On the Chinese side, however, there is generally a strident response to all hints that the incorporation is or was tainted, and that response falls back on the Marxist notions of history and its teleological movement (not particularly recognised as such, but so internalised as to be nonetheless a recognisable part of official Chinese assertions on Tibetan history). Such rigid ideologically-rooted teleology refuses to be ignored; accordingly, one of the constant conditions imposed on the Dalai Lama is that he publicly accept China's interpretation of Tibet's historical relationship with China.

\section{The assertion that Tibet became part of China under the Yuan Dynasty}

The primary debate over Tibet's status is thus a debate about history. Even when interlocutors are willing to sidestep the question of status, and by extension history, China generally asserts its case as a given. Hence, the locution commonly encountered in Chinese introductions to discussions about Tibet: "As everyone knows, Tibet has been an integral part of China for centuries" (or sometimes more precisely, "for over 700 years"-although, as will be seen below, even this limit is going by the wayside). In the international arena, Tibet's status as a part of China has been argued over for at least a century, but only over the last quarter century has China mobilised an intense array of studies and documents to support its case. (I) $^{(1)}$ The banner on the CCTV website $^{(2)}$ just cited is set over several links relating to Tibet, one of which asserts, "Historical records show Tibet a part of China." That link leads to a recent Xinhua report:

BEIJING, April 7 (Xinhua) - China's State Archives Administration on Monday published historical records that showed Tibet had been under jurisdic-

1. For examples of some of the documentation assembled in China to support the position that Tibet has historically been part of China, see Elliot Sperling, The TibetChina Conflict: History and Polemics, Washington, East-West Center Policy Studies, no. 7, 2004, pp. 37-38, note 10.

2. http://www.cctv.com/english/special/Tibethistory/02/index.shtml, 2 November 2008. 
tion of the central government for more than 700 years since the Yuan Dynasty (1271-1368).

The archives, including 15 official documents about the conferring of titles upon Tibetan officials or about the central government setting up offices in Tibet over history, were published via a video on the administration's website (www.saac.gov.cn).

"They are only a tiny part of the historical records," said Yang Dongquan, the administration's director.

"The records are indisputable proof that Tibet has been a part of China since the ancient time, and Tibet has been under jurisdiction of China's central government during the past 700 years," he said, adding any attempt to separate Tibet from China was not allowed.

According to the administration, the records include: - an edict issued by Emperor Thogan Themur to Yontan Gyaltshan in 1362 that appointed Yontan Gyaltshan as the Pacification Commissioner in Tibet. It showed the Yuan Dynasty's central government set up the Pacification Council in the capital Dadu and the Pacification Department in Tibet in order to exercise jurisdiction over the region.

- an edict issued by the first emperor of the Ming Dynasty (1368-1644) to Hrogskunrgyal, appointing him the general of Olisi, a post in charge of the military and administrative affairs of an ulterior region in Tibet.

The most interesting document in the batch, from the author's perspective, is the Ming document, since its inclusion is meant to underline a Ming inheritance of Mongol Yuan domination of Tibet. The edict in question is found in a volume entitled Xizang lishi dang'an huicui, published in Beijing in 1995. The actual language of the document is straightforward:

From the Emperor to Whom Heaven Has Entrusted Rule. An Imperial Decree.

We rule that which is under Heaven. In the four directions all who admire righteousness and return in allegiance to $U_{s}$ are treated with proper decorum and appointed with official positions. You, ${ }^{*}$ Shuk künkyab [Shuosi gongshi jian] have long dwelled in the Western lands and you have heard of Our renown and influence. You are able to follow your own inclinations, demonstrate loyalty and obedience, and maintain the security of the frontier territory. We praise this. Now We have established the Ngari Tribal Military Command and have ordered that you take up the post of Marshal. Moreover you should think things through thoroughly, be circumspect, and respect discipline, so as to suitably comfort the tribal masses and ensure peace in the frontier regions. Our intention for this appointment is to create the Huaiyuan General ["the General who Cherishes the Remote Lands"], Marshal of the Ngari Tribal Military Commission, and We appropriately order that *Shuk künkyab ${ }^{(3)}$ act according to this [appointment].

The $2^{\text {nd }}$ Month of the $6^{\text {th }}$ Year of Hongwu [23 February -24 March 1373(4)

At this point it becomes interesting. I underline that this appointment-viewed with such signal importance in the Xinhua press release, as well as within the archival collection within which it is presented-is dated to FebruaryMarch, 1373. It is striking, then to find an entry in the Ming shilu for February 10, 1375 recording that "[The emperor] ordered the creation of the Ngari Tribal Military Command, the Phagmo drupa brigade and the Ütsang Longda battalion. Thirteen officials were appointed." (5) This sort of appointment record is fairly well known within the study of Sino-Tibetan relations and relates to the administrative structures for dealing with those who engaged with the Ming in tribute relations and other frontier matters, in part by granting them titles. This was, after all, the time in which, if we were to go by such Ming notices, the whole of Tibet was governed from Hezhou (modern Linxia in Gansu) by one Wei Zheng, ${ }^{(6)}$ at least as of 23 August 1374. ${ }^{(7)}$ That, of course, was not the case, and Wei Zheng is essentially unknown in Tibetan history, in spite of his being placed by

3. The * refers to a phonological transcription of the Tibetan.

4. Xizang zizhiqu dang'anguann, Xizang lishi dang'an huicui (A Collection of Historical Archives of Tibet), Cultural Relics Publishing House, Beijing, 1995, doc. 23. The identification of Shuk Künkyab remains somewhat problematic. I am, however, indebted to Roberto Vitali for kindly pointing out to me the likely reconstruction of this person's surname as "Hrugs" (i.e., =Shuk, in vulgar phonetics) on the basis of both the Chinese rendering of the name (Shuosi) and the existence of the important Hrugs clan in the region. Indeed, this is the clan of the famous translator Rinchen Sangpo. See Guge Khyithangpa Dznyana shr, The Lamp of Austerities of the Successive Lives of the Bodhisattva Translator Rinchen Sangpo: A Continuous Crystal Rosary of Biography, Organizing Committee for the Commemoration of 1000 Years of Tholing Temple, McLeod Ganj, 1996, p. 12.

5. Gu Zucheng et al., Ming shilu Zangzu shiliao (Tibetan Historical Material of Ming History) Tibet People's Publishing House, Lhasa, 1982, p. 34

6. On Wei Zheng, see his biography in Zhang Tingyu et al., Mingshi (Ming History), Zhonghua Press, Beijing, 1974, 134:3905-3906.

7. See Gu Zucheng, Ming shilu Zangzu shiliao, op. cit., pp. 29-30. 

over the course of the first two decades of historical research and writing in the PRC and was in part spurred by the crisis of 1959. Prior to that time there was a period in which the assessment of Republican-era writers, that subjugation to the Mongols aside, Tibet had become a part of China during the Qing period, continued. Moreover, when Republican-era writers asserted China's claim to sovereign rights over Tibet, they tended to view Tibet as having been a vassal state of the Qing rather than (as the present-day Chinese position has it) an integral part of China. The terms used to categorise Tibet during the Qing, fanbang, fanshu, etc., are specific in that regard and can generally be rendered as "vassal state" or "dependent state."

The imperial paradigm that Republican-era writers used in describing Tibet's place in the Chinese state left no room for ambiguity. To choose from several examples, we find the following in a 1926 work:

Thus, in both the 57th and 58th years of the Qianlong period (1792 and 1793), the relationship between China and Tibet was radically reformed. China's sovereignty over Tibet was firmly established and afterwards implemented in practical terms.

From the time of the above-mentioned radical reform Tibet was purely reduced to a vassal state of China.

To China belonged not only suzerain rights over Tibet, but sovereign rights as well. ${ }^{(1)}$

This interpretation did not change immediately with the establishment of the People's Republic of China. Chinese pronouncements from that period avoided fixing a date for Tibet's incorporation into China, other than simply noting, as did the "Seventeen-Point Agreement on Measures for the Peaceful Liberation of Tibet," signed by representatives of the Dalai Lama's government and the central government of China on 23 May 1951, that "The Tibetan nationality is one of the nationalities with a long history within the boundaries of China." (II)

The conclusion that Tibet had become part of China during the Qing was not at first problematic. In 1953, four years after the establishment of the PRC, one of China's better-known writers on Tibet, Huang Fensheng, preserved this basic chronological element in his account of Tibet's history. ${ }^{(12)}$

Ultimately, it was the revolt in Lhasa and the flight of the Dalai Lama in 1959 that elicited clearer and more forceful formulations of the PRC's position on Tibet's historical status. In a volume titled Concerning the Question of Tibet, published the same year, it was stated on the one hand that
Tibet "has never been an independent country, but a part of China," ${ }^{(13)}$-a position that has recently been revisited, as will be discussed below-and on the other that the Mongols "sent an armed force to Tibet in 1253. Tibet was then incorporated into the Yuan Empire and it has been a part of the territory of China ever since." (14)

This notion that Tibet became an integral part of China during the Yuan period (1271-1368) remained a tenet of Chinese historiography in the decades that followed, and a growing number of books and articles supporting it appeared from the early 1980s on. A few references to some of these works will suffice to illustrate the general unanimity on the subject. There were, of course, anomalies. When the late Huang Fensheng's larger survey of Tibetan history was edited for posthumous publication, the editor, $\mathrm{Wu}$ Jun, noted that revisions were specifically needed with regard to the author's account of the Yuan and the Ming. ${ }^{(5)}$ Unlike Huang's earlier work, this volume conforms more closely to the interpretation that Tibet came under Chinese rule during the Yuan and not the Qing. However, owing perhaps to an editing slip, Tibet is said to have become simply a vassal state of China during the period of Mongol rule. ${ }^{(16)}$

General histories of Tibet published during this period give support, implicitly or explicitly, to Tibet's status as a part of China since the Yuan period. A few other examples are illustrative. Wang Furen and Suo Wenqing (1981):

In 1288 the Zongzhiyuan was renamed the Xuanzhengyuan (...). The areas of $U ̈$, Tsang, and Ngari, etc., in Tibet constituted its administrative scope. Thus, the entire country's Tibetan regions came under the central political administration of the Yuan Dynasty. ${ }^{(17)}$

10. Xie Bin, Xizang wenti (The Question of Tibet), Commercial Press, Shanghai, 1926, pp. 20-21 For other examples see Sperling, The Tibet-China Conflict: History and Polemics, op. cit., p. 38.

11. See Xizang zizhiqu dang'anguan, Xizang lishi dang'an huicui, op. cit., doc. 100.

12. Huang Fensheng, Xizang qingkuang (The Situation of Tibet), Map Publishing House, Shanghai, 1953, p. 111. See Sperling, The Tibet-China Conflict: History and Polemics, op. cit., p. 38.

13. Concerning the Question of Tibet, Foreign Languages Publishing House, Beijing, 1959, p. 195.

14. Ibid., p. 190.

15. Huang Fensheng, Zangzu shilüe (A Short History of the Tibetans), Nationalities Publishing House, Beijing, 1985, p. 9: "When I was doing the revisions, I divided those areas on which a basic consensus had already emerged into those to be corrected and those to be annotated, such as the administration of Tibetan regions during the Yuan and Ming, etc."

16. Ibid., p. 224: "In the late Yuan the Mongol ruling class's degeneration was relating to an excessive reverence for Tibetan Buddhism. Tibet went a step further and became a vassal state of China."

17. Wang Furen and Suo Wenqing, Zangzu shiyao (Highlights of Tibetan History), Sichuan Nationalities Publishing House, Chengdu, 1981, p. 75 
Chabpel Tshetän Phüntsok and Nortrang Orgyän (1990):

\begin{abstract}
Afterwards, the Yuan emperor [=Qubilai] installed a united guard force in Tibet and actually placed the governing power for maintaining Tibet in the hands of the Sakyapa. From then on Tibet was truly subject to the emperors of China. ${ }^{(18)}$
\end{abstract}

Gyälmo Drukpa (1995):

The ultimate result [of Qubilai's use of Tibetan religious figures in his governance] was to create deep and lasting friendship between the Tibetan and Mongol nationalities and to make tangible the great work of unifying the Motherland. ${ }^{(19)}$

The "Zangzu jianshi bianxiezu" ("The Committee for the Compilation of a Short History of the Tibetan Nationality," 1985):

This series of measures constituted the implementation in Tibetan regions of Qubilai's general policy to unify the country. The administrative systems established by the Yuan Dynasty in Tibet and other areas, though possessing characteristics that differed from those in the Chinese interior, were nevertheless a solid part of the whole country's administrative system under the direct administration of the Central government. ${ }^{(20)}$

This is a small sample of works asserting that Tibet's position as a part of China was established during the period of Mongol rule. I have limited these citations to general surveys of Tibetan history, with the specific aim of situating this position within the general construction of Tibet's historical past. Works that deal more specifically with the question of Chinese sovereignty over Tibet, and which also highlight the Yuan period as the crucial era in the establishment of that sovereignty, can also easily be found. ${ }^{(21)}$

The contrasting position from Tibetans outside Tibet is best exemplified by the writings Tsipön Shakabpa, who maintained that the relationship between Tibet and the Mongol rulers of the Yuan (and also with the Manchu rulers of the Qing) was not one of subordination, but rather a relationship between a "priest" and a "patron," misunderstood as one of sovereign and subject. His original Tibetan text located the roots of this misunderstanding within the oriental exceptionalism that rendered the "priest-patron" relationship impervious to Western political categorisation. ${ }^{(22)}$
Other Tibetan commentators outside the PRC also approached the question similarly. If they did not relegate the issue to a misinterpretation of an essentially religious relationship, then they simply framed it within religious terms. Khangkar Tshültrim Kälsang wrote that after receiving initiation from Phakpa, Qubilai granted him the 13 myriarchies of Tibet, after which "all of Tibet became subject to the Sakyapa." ${ }^{(23)}$ For his part, Dongtok Tänpä Gyältsän writes:

Thus, the country of Tibet was occupied by the Mongol royal lineage for forty-nine years. Ultimately due to Drogön chögyäl Phakpa of Sakya, not even the life of one human being was afflicted with hardship and via the path of ahimsa and peace, the three ölge of the land of Tibet were freed from foreign oppression and the civil and religious system existed with full independence. ${ }^{(24)}$

\section{The assimilation of Tibet into the People's Republic of China}

If Tibet is said to have become a part of China during the Yuan period, we may do well to look briefly at how the absorption of Tibet into the PRC is represented. For

18. Chabpel Tshetän Phüntsok and Nortrang Orgyän, Brief History of Tibet: A Turquoise Rosary, Ancient Texts Publishing House, Lhasa, 1990, pp. 56-57: de-rjes Bod-du Yon gong-ma'i gcig-gyur-gyi srung-dmag btsugs-te gzhi-nas Bod sa-gnas-kyi bdag-skyong dbang-cha de Sa-skya-ba'i 'og-tu gcig-bsdus byung-zhing/ de-nas-bzung Bod-'di Krung-go'i gong-ma'i mnga'-khongs-su dngos-su chod-pa yin/.

19. Gyälmo Drukpa, Discussion on the History of Tibet, Nationalities Publishing House, Beijing, 1995, p. 229: mthar-thug don-gyi 'bras-bu ni Bod-Sog mi-rigs bar-gyi mdza''brel dam-zab dang Mes-rgyal gcig-gyur yong-bar bya-bzhag rlabs-po-che gzugs-can Ita-bu 'di bskrun-pa lags-so/.

20. Zangzu jianshi bianxiezu, Zangzu jianshi (A Brief History of the Tibetan Nationality), Tibet People's Publishing House, Lhasa, 1985, p. 153.

21. See, among other works, Deng Ruiling, Yuan-Ming liangdai zhongyang yu Xizang difang de guanxi (Relationship between the Central Government and Tibetan Areas during the Yuan and Ming Dynasties), China Tibetology Publishing House, Beijing, 1989; Wang Gui et al., Xizang lishi diwei bian (A Discussion on Tibet's Historical Status), Nationalities Publishing House, Beijing, 1995; Wang Jiawei and Nima jianzan, Zhongguo Xizang de lishi diwei (Historical Status of China's Tibet), Wuzhou Propagation Publishing House, Beijing, 2000; and Zhang Yun, Yuandai Tufan difang xingzheng tizhi yanjiu (A Study of the Administrative System of Tibetan Areas Under Yuan Dynasty), Chinese Academy of Social Sciences Publishing House, Beijing, 1998.

22. See Sperling, The Tibet-China Conflict: History and Polemics, op. cit., pp. 19-20, quoting Shakabpa's original Tibetan text.

23. Khangkar Tshültrim Kälzang, Tibet and the Tibetans: A Compendium of Tibetan History, New Delhi, Western Tibetan Cultural Association, 1980, p. 139: 'di-nas bzung Bodkhams thams-cad Sa-skya-ba'i mnga'-'bangs-su gyur/.

24. Dongtok Tänpä Gyältsän, A History of Snowy of Tibet: Unprecedented Analytical Annals of Movemented Years and Times, A Melody that Rejoices the Learned Witnesses, Sapan Institute, Shoreline WA, 2002, p. 173: de-Itar Bod rgyal-khab Hor rgyal-rgyud-kyis lo bzhi-bcu-zhe-dgu'i ring btsan-bzung byas mthar/ Sa-skya'i 'Gro-mgon chos-rgyal 'Phags-pas 'gro-ba mi-gcig-gi tshe-srog-la'ang gnod-'tshe ma-phog-par 'tshe-med zhi-ba'i lam-nas Bod-yul chol-kha gsum phyi-rgyal-gyi btsan-gnon 'og-nas thar-te chos-srid gnyis-Idan rang-btsan gtsang-ma'i gnas-la bkod mdzad... 
indeed, if Tibet was already part of China for centuries before 1951, then the incorporation of Tibet into the PRC ought to require serious explanation in Tibetan and Chinese discussions of history.

As with the historical studies produced in the PRC, Tibetans in exile have also produced non-global studies of specific, circumscribed areas of Tibetan history and Tibet's relationship with China. ${ }^{(25)}$ When we turn to the question of Tibet and the PRC, something striking is immediately noticeable. While Shakabpa's history of Tibet carries the story past the events of 1950-1951 and discusses the rise of discontent in Tibet, culminating in the uprising of the 1950s and early 1960s, he is almost alone in this. The other Tibetan histories published outside the PRC that have been cited above tend to present Tibet's history against a stronger background of religious developments and end the story in the middle of the twentieth century. To be sure, there are important Tibetan accounts of Tibet under Chinese rule and, importantly, memoirs relating to the rebellion in the 1950s and subsequent resistance. ${ }^{(26)}$ But they are somehow separate from the longer view of Tibetan history, and the events they cover are for the most part not integrated into volumes taking a holistic approach to Tibetan history.

The same is largely true of the works published in the PRC, even though the emphasis in them is not so strictly focused on the religious factor in Tibetan history. One cannot simply assume that the nature of the events of the period, especially under the present diplomatic and political circumstances, remains too sensitive, since there are non-global histories of Tibet that do deal with the post- 1950 period. Surely this historical divide is in part owing to the establishment of the PRC in 1949 being treated as a major watershed in Chinese history in general. In Tibet, however the integration of that period into a global view of Tibetan history is problematic for other reasons as well. Several of the histories adopt a teleological view of history's workings. This is quite clear in Dungkar Lobzang Trinlä's A Discussion of the Tibetan Dual Political and Religious System, ${ }^{(27)}$ wherein the evolutionary view of Tibetan history (via Hegel and Marx) is clearly enunciated, and wherein the culmination of the integrated religious and political system of Tibetan government is reached, historically, with the rise and fall of Gandän Photrang, the traditional Tibetan government. Thus the break is clear, and Tibetan history post-1950 is set aside as another subject-even though the Dalai Lama's government functioned in Tibet up to 1959 .

For Shakabpa the break is not so absolute: in his eyes, the establishment of a Tibetan Government-in-Exile is a contin- uation, not simply of Tibetan polity, but of Tibetan history. But he is somewhat unique in this outside the PRC. For others we may speculate that the absolute break in history, to the point of ending the narrative in the middle of the twentieth century, is due to the manner in which Tibet within the PRC is viewed from exile: the government within Tibet is no longer a Tibetan government, and cultural continuity is now viewed has having been displaced to India. The policies followed by China in the decades prior to the rise of Deng Xiaoping have certainly contributed greatly to the perception of a tremendous rupture.

The disconnect between pre-1950 and post-1950 Tibetan history presented within the PRC is somewhat different. There is a clear sense, already noted with regard to Dungkar Lobzang Trinlä, that the "liberation" of Tibet was the culmination of a definite historical process. This then also places Tibet within the periodisation schemes that prevail within modern Chinese historiography. In particular, Tibet's history in the twentieth century falls into the categorisation given over to both "contemporary" (dangdai) and "modern" (jindai) history.

There are studies of various individual topics related to Tibet's modern history published within the PRC: the pacification of Tibet in the aftermath of the 1959 uprising in Lhasa, volumes dedicated to the work in Tibet of important figures from the 1950s (Zhang Jingwu, Tan Guansan, Zhang Guohua, etc.), memoirs of Tibet work in the 1950s, and several books dealing with the Tibet-related work and thought of Mao Zedong and Zhou Enlai, etc. ${ }^{(28)}$ But at least two volumes deal with recent Tibetan history in accord with

25. See Domäpa Yöntän Gyatso, Proof that Tibet Can Absolutely Not Be Called a Part of China: The Quintessence of Truth, Office of International Relations, Dharamsala, 1991; Dzongtse Champa Thubtän, The Evolution of the Priest-Patron Relationship between Tibetans, Mongols and Manchus, Library of Tibetan Works and Archives, Dharamsala, 2000; and An Analysis of the Relation between Tibet and Manchus, in Five Periods, Dharamsala, Research and Analysis Centre, Department of Security, 1999.

26. For example: Gadraupön Rinchen Tshering and Chamdo Drungyig Lobzang Wangdü eds., History of Chushi gangdruk, Welfare Society of Central Dokham Chushi Gangdruk, Delhi, 2000; and Tsongka Lhamo Tshering, Resisting Agression, Dharamsala, Amnye Machen Institute, 1992.

27. Dungkar Lobzang Thrinlä, A Discussion of the Tibetan Dual Political and Religious System, Nationalities Publishing House, Beijing, 1981, pp. 1-3.

28. See, for instance, Xizang geming huiyilu (Memoirs of the Revolution in Tibet), Tibet People's Publishing House, Lhasa, 1981; Lin Tian, Xizang chunqiu (Tibet Annals), China Tibetology Publishing House, Beijing, 1990; Xiao Hao, Xizang 1951 nian (Tibet in 1951), Nationalities Publishing House, Beijing, 1999; Zhao Shenying, Zhongyang zhu Zang daibiao Zhang Jingwu (Zhang Jingwu, Commissar of the Central Government in Tibet), Tibet People's Publishing House, Beijing, 1995; Jiangbian jiacuo, Xueshan mingjiang Tan Guansan (The Famous General Tan Guansan in the Snow Moutains), China Tibetology Publishing House, Beijing, 2001; Zhao Shenying, Zhang Guohua jiangjun zai Xizang (General Zhang Guohua in Tibet), China Tibetology Publishing House, Beijing, 1998; Mao Zedong Xizang gongzuo wenxuan (Selected Works of Mao Zedong on Tibet), China Tibetology Publishing House, Beijing, 2001; and Zhou Enlai yu Xizang (Zhou Enlai and Tibet), China Tibetology Publishing House, Beijing, 1998. 
the categorisation just mentioned. One, Xizang difang jindaishi, ${ }^{(29)}$ is, as its title notes, a history of Tibet in the modern era. It deals with Tibet largely from during the nineteenth century and the first half of the twentieth, in keeping with the understanding of "modern" history in China. The second, Dangdai Xizang jianshi, ${ }^{(30)}$ is a brief history of Tibet in the "contemporary" era, and thus deals almost exclusively with the post-1950 period. In spite of its characterisation as a "brief" history, it runs to almost 500 pages. Within those pages the treatment of the beginnings of Tibet's integration into the PRC merits a brief comparison with the approach taken by writers outside the PRC. Thus, the following description of the prelude to the People's Liberation Army's advance into Tibet:

In spite of the Tibetan local authorities' stubborn adherence to a separatist stance and even their efforts at anti-communist propaganda within the Tibet region, the guiding principles for the Central Government's peaceful resolution of the Tibet Question were nevertheless still communicated to Tibet via broadcasts and other channels, eliciting a strong response from among upper-strata figures and the masses. Some people absolutely disapproved of Takdra throwing his lot in with imperialism and undertaking Tibetan "independence" activities. In May, 1950, Kalön Lhalu Tshewang Dorje's term as Chamdo Chikyab was up and none of the three Kalön in Lhasa wanted to go out and replace him. So the Regent Takdra broke precedent and promoted Tsipön Ngapö Ngawang Jigme to be a supplementary kalön, replacing Lhalu in the post of Chamdo Chikyap. Ngapö made it clear that they should not oppose the Communist Party, but rather enter into peace talks with the Communist Party. However, his views were not accepted by the authorities. The three major monasteries and some upper-strata figures also did not advocate armed resistance to the People's Liberation Army. The broad mass of the Tibetan People heard, via merchants who travelled between Xikang and Tibet, of the model behaviour of the PLA in the Tibetan regions of Xikang, where they had strictly adhered to nationality policy and respected the Tibetan people's religious beliefs, customs, and habits. They hoped even more so that the PLA would advance into and garrison Tibet at an early date. The unification of the Motherland, the unity of the people of all nationalities, common progress: these have formed the main current of the historical development of the Chinese People for thousands of years. The adherence of the Tibetan local authorities to a separatist stance and their resistance to the liberation of Tibet received no popular support. ${ }^{(31)}$

The operative teleology here is evident in the reference to the "main current of the historical development of the Chinese People." It serves to connect the historical narrative that developed after 1959, with Tibet becoming a part of China during the Yuan Dynasty, to the understanding of Tibet's "liberation" in 1951: both are part of an inevitable linear process. This obviously distinguishes the foregoing passage from the kind of accounts found circulating among Tibetans outside the PRC. There, the approach to this period of Tibetan history has been straightforward political narrative, largely based on the perception that Tibet's relations with China were rooted in the "priest-patron" relationship, and the continuity of Tibet's independence. Thus, we can see the place of the relationship that Tibet entertained with the Yuan Dynasty reflected in Shakabpa's narrative up into the twentieth century. Indeed, Shakabpa recounts the Tibetan government's insistence, in pre-1950 correspondence with the new Chinese government, on the "priestpatron" relationship as the proper form of relations between Tibet and China. Chinese claims beyond that, he maintains, were historically baseless:

In October, 1949, the Earth-Ox year, the Red Chinese Communist Party, after taking all of China, publicly proclaimed, again and again, over the radio from Beijing and from Xining, in Amdo, baseless proclamations stating that because Tibet was a part of China, the People's Liberation Army was to be sent into Tibet to liberate Tibet from the oppression of foreign countries; and that the Tibetan people must revolt against the Dalai Lama's government $\left(. .{ }^{(32)}\right)$

29. Xu Guangzhi, Xizang difang jindaishi (History of Tibet in the Modern Era), Tibet People's Publishing House, Lhasa, 2003.

30. Danzeng, Dangdai Xizang jianshi (Short History of Contemporary Tibet), Beijing, Contemporary China Publication House, 1996.

31. Danzeng, Dangdai Xizang jianshi, op. cit., p. 45

32. Shakabpa Wangchuk Dedän, A Political History of Tibet, Shakabpa House, Kalimpong, 1976, vol. 2, pp. 408 ff: sa-glang 1949 spyi-zla 10 nang Rgya-dmar gung-bran-tangnas Rgya-nag yongs-rdzogs blangs-rjes/ Be-cing dang/ Mtsho-sngon khul Zi-ling-nas yongs-grags rlung-'phrin thog brjod-gsal/ Bod-ni Rgya-nag-gi khongs-gtogs-shig-yinpas phyi-rgyal btsan-dbang rgyal-khab-kyi 'og-nas bcings-bkrol-gtong-bar Rgya-dmargyi bcings-bkrol dmag-mi Bod nang-la gtong-rgyu yin-tshul dang/ Bod-kyi mi-dmangsnas T-la'i bla-ma'i gzhung-la ngo-log rgyag-dgos sogs khungs-med-kyi khyab-grags yang-yang byas. . 
The Tibetan-Mongolian Treaty of 1913 (c) All rights reserved.

Khangkar Tshültrim Kälzang describes Chinese claims to Tibet in a manner that draws on Shakabpa:

In 1949, after taking all of China, the Red Chinese made baseless proclamations about how Tibet belonged to China, in response to which the Tibetan government answered from the Lhasa Broadcasting House that Tibet was independent. In 1950 the Red Chinese invaded Tibet and reached Chamdo. ${ }^{(33)}$

Shakabpa also makes no mention of conflict between the Tibetan government and Ngapö, prior to his dispatch to Khams mentioned in the Chinese account cited above:

As the term of Shabpä Lhalu Tshewang Dorje, the official in charge of civil and military affairs in Eastern Tibet, was at an end, Tsipon Ngapö Ngagwang Jigme was named kalön, so as to be his new replacement. He was appointed Domä Chikyap and arrived in Chamdo with his staff. ${ }^{(34)}$

\section{The Tibeto-Mongol Treaty}

This brings us to another element worth examining. Having discussed the presentation of Tibet's history with regard to assertions of Tibet's transformation into a part of China, we can turn briefly to the presentation accorded an historical assertion of Tibet's independence. This is the TibetoMongol Treaty, concluded in 1913 by Tibet and Mongolia following the collapse of the Qing. ${ }^{(35)}$

In China, references to the treaty's existence have at times also been dismissive, with one publication on the Tibet issue referring to the "so-called 'Mongolia-Tibet Treaty' that was much rumoured at the beginning of 1913." (36) Other publications have cast the treaty as a tool for Russian penetration of Tibet, and consider it ultimately invalid. ${ }^{(37)}$

The treaty actually appeared in Chinese references during the Republican Period. For the most part, knowledge of its contents was drawn from the description given by Sir Charles Bell in 1928 in Tibet: Past and Present. ${ }^{(38)}$ Xizang waijiao wenjian (Diplomatic Documents on Tibet), compiled by Wang Guangqi in 1929, consists largely (as its title indicates) of translations of those documents relating to Tibet's contacts with foreign countries presented by Bell in the appendices to Tibet: Past and Present. Commentary for some of the documents, including the Tibeto-Mongol Treaty, is also provided; the short commentary on the treaty is translated in part from Bell. The treaty itself is given in English and Chinese ver-

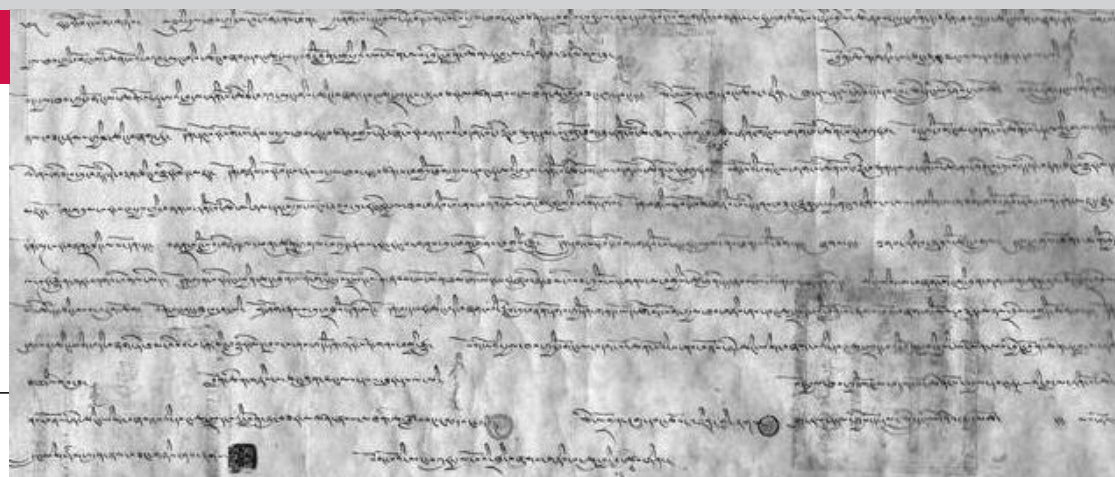

sions, ${ }^{(39)}$ though it is important to note that Bell's English version is not a direct translation from the document's original Tibetan text.

A more recent work, Zangzu jianshi (A Brief History of the Tibetans), repeats (and cites) Bell's assertions about the treaty's status as unfounded rumour-a rumour denied by the Dalai Lama, according to Bell. ${ }^{(40)}$

A 2001 Chinese study of British and Russian penetration of Tibet, Yingguo Eguo yu Zhongguo Xizang (Britain, Russia and Chinese Tibet), departs from the extensive reliance on Bell where the treaty is concerned, and draws from Russian writings and British Foreign Office materials. The account of the treaty found here notes that correspondence between the British and Russian governments in the first months following the conclusion of the treaty expressed common agreement that the treaty was not a valid international instrument. ${ }^{(41)}$

It would be useful to present here an English translation of the treaty directly from the Tibetan, as no such translation has yet been made. Indeed, the Tibetan text only became available from the Mongolian State Archives three years ago. As can be seen in the text, the treaty clearly asserts the independence of Tibet-and Mongolia-at the very outset:

[1] Both Tibet and Mongolia have each emerged from under the domination of the Manchu state. Having separated from China, Tibet and Mongolia have constituted themselves as independent nations. From early times up to the present both Tibet and Mongolia have had very close relations based on their identical esteem for the [Buddhist] Doctrine. Thus,

33. Khangkar, Tibet and the Tibetans: A Compendium of Tibetan History, op. cit., p. 620.

34. Ibid., pp. 414-415: Mdo-smad zhi-drag spyi-'doms zhabs-pad Lha-klu Tshe-dbang rdorje dus-rdzogs-pas tshab-gsar-du rtsis-dpon Nga-phod Ngag-dbang 'jigs-med-la bka'blon bsko-gzhag gnang-thog/Mdo-spyi'i las-'khur stsal-te ngo-las rnams Chab-mdor 'byor/

35. I am preparing a separate article dealing solely with the treaty.

36. Jing Wei, 100 Questions About Tibet, Beijing Review Publications, Beijing, 1989, pp. 19

37. See, for example, Zhou Weizhou, Ying-E qinlüe woguo Xizang shilüe (A Brief History of English and Russian Invasion of Our Tibet), Shaanxi People's Publishing House, Xi'an, 1984, pp. 239-240.

38. Sir Charles Bell, Tibet: Past and Present, The Clarendon Press, 0xford, 1924, pp. 151 and 304-305.

39. Wang Guangqi, tr., Xizang waijiao wenjian (Diplomatic Documents on Tibet), Taiwan Student Book Company, Taipei, 1973, pp. 20-21 and 129-136.

40. Zangzu jianshi bianxiezu, Zangzu jianshi, op. cit., p. 365

41. Zhou Weizhou, Ying-E qinlüe woguo Xizang shilüe, op. cit., p. 369. Note that the term used here for the treaty is xieding, denoting an "accord." 
for the sake of concluding a treaty in furtherance of yet greater firmness [in their relations], the foreign ministry [Tib. ya-mon < Ch. Yamen; "government office"] officer and plenipotentiary invested, by order of the Great Emperor of the Mongolian [2] Nation, with treaty-making powers, Da blam-a Ni ta Biligtü [Tib. T bla-ma Nyig-tha sbi-legs-thu] Rabdan; and the secondary high minister, ang un Manglai Ba'atur Beyile [Tib. Cang-cun (<Ch. Jiangjun; "general") Lmang-las Dpa'-thur Dpal-li] Damdingsürün; [3] along with the plenipotentiary invested, by order of the precious Dalai Lama, Great Emperor of Tibet, with treaty-making powers, the Personal Attendant and Monk [of the Dalai Lama], Lobzang Ngawang; the Liason Officer [of the Dalai Lama], Ngawang Chödzin; the Cleric Official [attached to the Potala; i.e., under the Dalai Lama] and Manager of the [Dalai Lama's] Urga Bank Holdings, Yeshe Gyatso; and the Assistant Secretary Gendün [4] Kälzang have concluded a treaty as follows:

Article One. The Mongols have established an independent state and on the $9^{h}$ day of the $11^{\text {th }}$ month honoured the lord of the Yellow Hat doctrine, the Precious Jetsün dampa Qutu tu [Tib. Hu-thog-thu] as Great Lord and Emperor. The praise from Tibet's Great Lord and Emperor, the [5] precious Dalai Lama is firm and unchanging.

Article Two. The Tibetans have established an independent state and honoured the victorious and powerful precious Dalai Lama as Great Lord and Emperor. The praise from Mongolia's Great Lord and Emperor, the precious Jetsün dampa Qutu tu [6] is firm and unchanging.

Article Three. In order that the precious doctrine of the Buddha spread undiminished, both states must make every effort through consultations and discussions.

Article Four. Henceforth both Tibet and Mongolia shall afford each other aid and assistance against internal and external threats.

[7] Article Five. Each side shall provide aid within their own territories to those travelling between them on religious or civil affairs or for religious or civil studies.

Article Six. For the [8] realization of the full potential of commerce between both Tibet and Mongolia in such things as the goods, livestock and skins that they produce, as well as in monetary exchanges, there shall be, as before, no obstructions.
Article Seven. From now on, when loans are made, at the time they are handed over an office [Tib. ya-mon] seal should be requested. If it is sealed but not kept fixed there can be no grounds for petitioning the office in pursuit of the loan. Either party holding debts predating the conclusion of this treaty, for which [9] there has been actual ___[? unclear], are permitted to pursue those debts and get repayment. However, this is not the responsibility of one's own Šabi or Qosi un [Tib. Sha-spi Ho-shon-rnams; i.e., the monastic estate authorities or the banner authorities].

Article Eight. Following the conclusion of this treaty, if there is an issue that requires an amendment, the two states, Tibet and Mongolia, may convene joint discussions between their appointed plenipotentiaries.

Article [10] Nine. This treaty has been concluded, and from the time the seals are applied, firm and unchanging, it is, accordingly, set and fixed, sealed by the foreign ministry officer and plenipotentiary invested, on the part of the Great Lord and Emperor of the Mongolian Nation, with treaty-making powers, $D a$ blam-a Ni ta [11] Biligtü Rabdan; and the secondary high minister, ang un Manglai Ba'atur Beyile Damdingsürün; along with the seal [The seal is affixed here] of the minister-plenipotentiary [12] appointed and invested by the precious and victoriously powerful Dalai Lama, Great Lord and Emperor of Tibet, with treaty-making powers, the Personal Attendant and Monk [of the Dalai Lama], Lobzang Ngawang; the seal [The seal is affixed here] of the Liason Officer [of the Dalai Lama], Ngawang Chödzin; the Cleric Official [attached to the Potala; i.e., under the Dalai Lama] and Manager of the [Dalai Lama's] Urga Bank Holdings, Yeshe Gyatso; and the Assistant [13] Secretary Gendün [4] Kälzang.

The second throne year of the Mong-bkur king of the Mongols, the $4^{\text {th }}$ day of the $12^{\text {th }}$ month of the WaterMouse Year [11 January 1913].

\section{"Since ancient times": The new view of Tibet's relationship with China}

This concluding section will deal with a very recent development that portends a distinct shift in the polemics over Tibet's history. The trends in China's historiography on Tibet that we have described above-that Tibet became a part of China during the Yuan Dynasty-have held for sever- 
al decades. The new position is a more uncompromising one with a much larger claim on history. This new position holds that Tibet has been a part of China "since ancient times," i.e., since well before the Yuan. This change appears to be part and parcel of a broader Chinese assertiveness on the Tibet issue that has developed in the wake of the series of events in 2008 that left China defensive about Tibet but ultimately, following the Summer Olympics and the unfolding of the global financial crisis, in a stronger position as a rising global power. Much as China has made a public show of discarding the charade that led a large number of credulous observers to think that China was amenable to a compromise with the Dalai Lama over the Tibet issue, so too a hardened position over Tibet's historical status has emerged. The recent pronouncements are significant because they show the broad agreement and even common language that characterises positions that have been sanctioned as official policy. So it would seem with this case. Several reports of this new position have emerged. Most significantly, a Xinhua news dispatch of 5 May 2008 imparted a tone of official authorisation as it proclaimed "[The assertion that] 'Tibet has been a part of China since ancient times' is built upon an already existing theoretical base in Chinese historical geography."

And indeed, the theoretical element in this new historical view is laid out very clearly, drawing on the work of Tan Qixiang (1911-1992), the renowned scholar of China's historical geography. The article quotes what it views as a seminal paper by him from 1981 on "Historical China and China's Dynastic Frontiers," a paper that put things very clearly:

How do we handle the question of historical China? We take the territory of the Qing Dynasty, after its complete unification and prior to the encroachment of imperialism on China, specifically China's territory from the 1750s to the 1840s, the period preceding the Opium Wars, as the historical sphere of China. What is termed historical China is this sphere. Whether it's a question of centuries or millennia, the nationalities active within this sphere are considered by us to be China's historical nationalities; the regimes established within this sphere are considered by us to be China's historical regimes. This is the simple answer. Beyond this sphere lie no Chinese nationalities or Chinese regimes.

(...) Some comrades take Tufan [i.e., imperial-era Tibet] to be a part of the Tang Dynasty; this goes against historical reality. The Tang and Tibet struggled many times as enemies and marital alliances and friendly relations were rare. And when there were marital alliances and friendly relations, the Tang absolutely did not control Tibet. The relationship between the Han Dynasty and the Xiongnu and that between the Tang Dynasty and the Turks and Uyghurs was essentially the same. We can only recognize that Tufan, the Xiongnu, the Turks and the Uyghurs were part of historical China; but we can't say that they were part of the Han or Tang Dynasties. ${ }^{(42)}$

Adding to this, the Xinhua article then goes on to state:

[The assertion that] "Tibet has been a part of China since ancient times" is built on the base of Tan Qixiang's famous thesis. It's just as when we speak of Xinjiang, Inner Mongolia, Ningxia, the Northeast, Taiwan, Yunnan, Guizhou, Hunan and Hubei, Guangdong and Guangxi, and even Beijing and Nanjing, etc.: these places have been part of China since ancient times. There's no need to delve deeply into the question of when they fell under effective administration by the political authority of the Central Plain or of the central government. ${ }^{(43)}$

This is not isolated political rumination. Indeed, I would venture that this represents a new tack in the polemical case being made over Chinese historical claims to Tibet. Others articles have appeared echoing the premise set out here. With a clear stamp of authority, Sun Yong, vice-director of the Tibetan Academy of Social Sciences, gave an interview to journalists from Renmin Ribao that appeared on the paper's website on 26 February 2009, and that set out the points raised in the Xinhua piece with very precise relevance to Tibet:

When we say today that Tibet has been a part of China since ancient times, it is an historical fact. To say "since ancient times" is not the same as saying "since the Yuan Dynasty;" it is rather to say "since human activity began." In this regard saying "Tibet has been a part of China since ancient times" is also not to say "the regime in Tibet since ancient times

42. http://news.xinhuanet.com/politics/2008-/05/content_8106611.htm, 14 May 2009 43. Ibid. 
has always been a part of the area effectively governed by political authority from the Central Plains or the political authority of the Central Government." Rather, it's to say that "the history of this piece of land, Tibet, has, since human activity began, been a part of Chinese history." Whether it's as a part of the history of China's borderlands or as a part of the history of China's minority nationalities, it is nevertheless absolutely not part of the history of any foreign country. The formulation "only after Tibet entered into China's territory during the Yuan Dynasty did it become a part of China" has an obvious flaw. The famous Tibetologist Wang Furen pointed out in the 1980s that saying Tibet entered China's territory during the Yuan Dynasty is tantamount to saying Tibet had a period outside the Motherland; that prior to the thirteenth century Tibet was not within China. This does not accord with the historical fact of the evolutionary process of China's historical inseparability.

(...) Since ancient times each of the fraternal nationalities have been creating our great Motherland all together. This accords with the verdict of historical development. This sort of thesis is called the "Since Ancient Times Thesis" and the "All Together Thesis." According to the "Since Ancient Times Thesis" and the "All Together Thesis" within the formative sphere of Ancient China's boundaries, the nationalities that were active at that time within ancient China are the source of the modern Chinese nationality. The history of the formation and development of these nationalities is an organic part of China's history; the political regimes they established, whether they were central dynasties or regional regimes, were all political regimes within China. Seen this way, we can reach a clear conclusion: the history of the Tibetan nationality since ancient times is a composite part of the nationality history of China. The Tibetan nationality has, since ancient times, lived within the frontiers of China. Within the formation of the frontiers of ancient China the Tibetan nationality was an important member of the big multi-national family of China. The Tibet area that the Tibetan nationality inhabits has been a part of China since ancient times. ${ }^{(4)}$

It is fitting to end with a few words on this apparent change in polemical thinking. The argument's premise is strikingly simple: the boundaries reached by the Qing Dynasty at its height represent historical China, and within that area there is only Chinese history. While it is problematic for many scholars to consider the Qing in its entirety a Chinese state, that is irrelevant for the proponents of the "Since Ancient Times" thesis, which effectively asserts Chinese historical dominion retroactively. There is thus no need to quibble over whether or not the Ming exercised control over Tibet following the fall of the Yuan. In fact, it may perhaps be that the weaknesses in the Yuan-based case for Chinese sovereignty over Tibet, mentioned above, have played a role in this change in polemics. In any event, the new thesis treats all historical polities within the Qing borders at their furthest extent as Chinese regimes, much as historians have done with competing dynasties in China during eras of division. Sun Yong therefore asserts that an area such as Tibet has no history other than as a part of China, starting from the time that human activity began on the Plateau. Within the bounds of this thesis there is simply no independent Tibetan history. It sounds ludicrous, but there it is. The further ramifications of this mind-boggling proposition should prove interesting, for the thesis also appears to allot no place to independent Mongol history and to ascribe to certain areas that are today under India, such as those in Arunachal Pradesh, only a Chinese history since time immemorial. One thing above all is clear about this: China continues to take the historical argument over Tibet's status very seriously.

44. http://big5.people.com.cn/gate/big5/xz.people.com.cn/GB/139187/139208/ 8871595.html, 16 May 2009. My attention was originally drawn to this interview through a post about it on the website of Taiwan Xuangouzi: http://lovetibet.tida.net/e2642725.html 16 May 2009. 


\begin{tabular}{|c|c|c|c|}
\hline Glossary & & Zangzu jianshi bianxiezu & 藏族簡史編窎組 \\
\hline Xizang lishi dang'an huicui & 西藏歷史檔案薈萃 & dangdai & 當代 \\
\hline Shuosi gongshi jian & 搠思公失監 & jindai & 近代 \\
\hline Ming shilu & 明實錄 & Zhang Jingwu & 張經武 \\
\hline Hezhou & 河州 & Tan Guansan & 譚冠三 \\
\hline Linxia & 臨夏 & Zhang Guohua & 張國華 \\
\hline Wei Zheng & 韋正 & Xizang waijiao wenjian & 西藏外交文件 \\
\hline fanbang & 藩邦 & Wang Guangqi & 王光祈 \\
\hline fanshu & 藩屬 & Yingguo Eguo yu Zhongguo Xizang & 英國俄國与中國西藏 \\
\hline Huang Fensheng & 黄檑生 & Yamen & 衙門 \\
\hline Wu Jun & 吴均 & Jiangjun & 將軍 \\
\hline Wang Furen & 王轐仁 & Tan Qixiang & 譚其驤 \\
\hline Suo Wenqing & 索文清 & Tufan & 吐蕃 \\
\hline
\end{tabular}

List of Tibetan terms and book titles, with Tibetan original and meaning

Phonologic transcription translation

A Discussion of the History of Tibet

A Discussion of the Tibetan Dual Political and Religious System

A Political History of Tibet

An Analysis of the Relation between Tibet and Manchus, in Five Periods

Annals Without Precedent that Investigate the Passage of Time in the History

of Snowy Tibet. A Melody to Delight the Learned Witness

Brief History of Tibet. A Turquoise Rosary.

Chabpel Tshetän Phüntsok

Chamdo

Chamdo Drungyig Lobzang Wangdü

Chikyab

Domä

Domäpa Yöntän Gyatso

Dongtok Tänpä Gyältsän

Drogön chögyäl: Protector of all Beings, dharmaraja (epithet)

Dungkar Lobzang Trinlä

Dzongtse Champa Thubtän

Gadraupön Rinchen Tshering

Gandän Photrang: Traditional Tibetan governement (epithet)

Gendün Kälzang

Guge Khyithangpa Dznyana shri
Tibetan

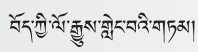

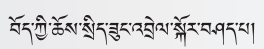

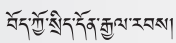

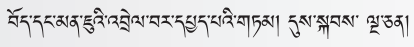

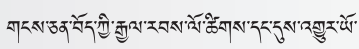

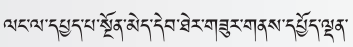

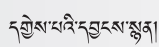

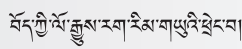

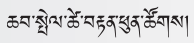

ธतअरॉ।

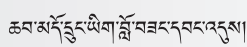

त्रों ब्रत्या

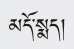

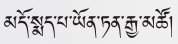

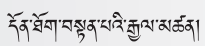

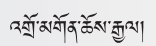

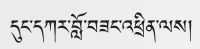

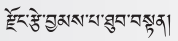

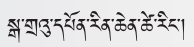

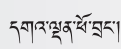

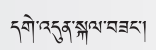

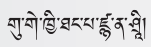

Category

Book title

Book title

Book title

Book title

Book title

Book title

Name of person

Place

Name of person

Governor

Place

Name of person

Name of person

Epithet

Name of person

Name of person

Name of person

Epithet

Name of person

Name of person 


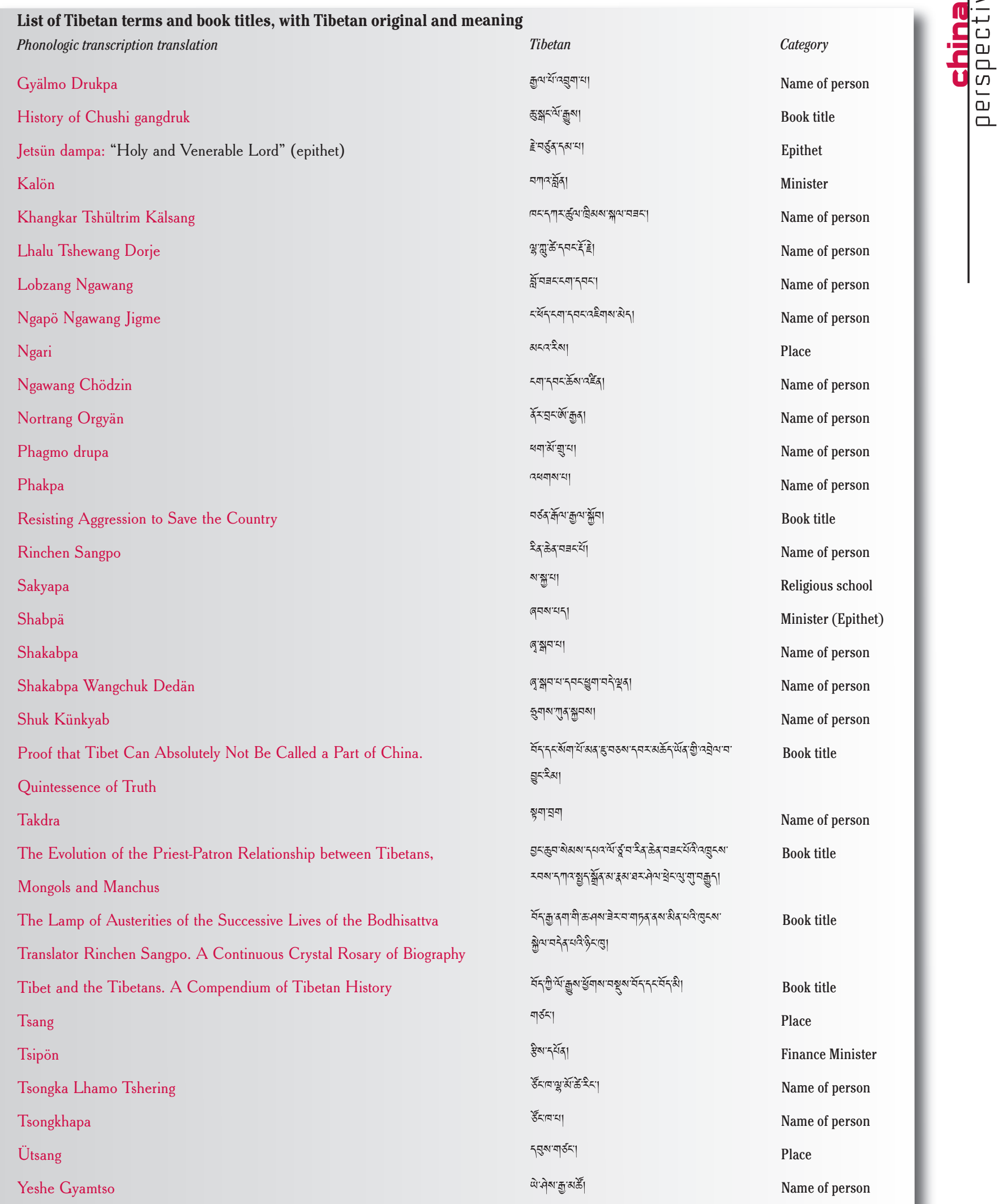

